\title{
The effects of acute administration of the hydroalcoholic extract of rosemary (Rosmarinus officinalis L.) (Lamiaceae) in animal models of memory
}

\author{
Camila Angela Zanella1, Helen Treichel², Rogério Luis Cansian, Silvane Souza Roman,*
}

${ }^{1}$ Department of Biological Sciences, Faculty of Biological Sciences, Regional Integrated University of High Uruguay and Missions, URI-Campus Erechim, ${ }^{2}$ Department of Food Engineering, Regional Integrated University of High Uruguay and Missions, URI-Campus Erechim, ${ }^{3}$ Department of Health Sciences, Faculty of Biological Sciences and Pharmacy, Regional Integrated University of High Uruguay and Missions, URI-Campus Erechim

\begin{abstract}
Rosmarinus officinalis (Rosemary) demonstrates antioxidant, antidepressant, diuretic, antinociceptive and antiulcerogenic activities. The present study was designed to examine the effects of the hydroalcoholic extract of $R$. officinalis on the memory of male mice. The behavioral tasks employed were social recognition (SR), the Morris water maze (MWM) and an inhibitory avoidance task (IA). The treatment with 150 and $300 \mathrm{mg} / \mathrm{kg}$ of $R$. officinalis improved the acquisition phase of learning of a new social memory in the SR task because a decrease was observed in the duration of social investigation. In the Morris water maze, no significant effect was observed on spatial memory when the groups were compared for the time spent in the correct quadrant. In the inhibitory avoidance task, the decrease in the stepdown latencies in the test session indicate that $150 \mathrm{mg} / \mathrm{kg}$ of $R$. officinalis improved long-term memory when administered in the consolidation phase of learning. In conclusion, the present study showed that, the hydroalcoholic extract of $R$. officinalis at 150 and $300 \mathrm{mg} / \mathrm{kg}$ modulated the short- and long-term memories of mice, in a social recognition and inhibitory avoidance task, respectively. This modulator effect was shown to improve learning and memory processes.
\end{abstract}

Uniterms: Rosmarinus officinalis/pharmacognosy. Rosmarinus officinalis/hydroalcoholic extract/ experimental study. Short-term memory/experimental study. Long-term memory/experimental study. Spatial memory/experimental study.

Rosmarinus officinalis L. (Alecrim) possui atividade antioxidante, antidepressiva, diurética, antinociceptiva e antiulcerogênica. O presente estudo foi delineado para investigar o efeito do extrato hidroalcoólico de $R$. officinallis na memória de camundongos machos. Os modelos comportamentais utilizados foram a tarefa de reconhecimento social (RS), labirinto aquático de Morris (MWM) e esquiva inibitória (EI). O tratamento com 150 e $300 \mathrm{mg} / \mathrm{kg}$ de R. officinallis, mostrou ter efeito positivo na aquisição de uma nova memória social, na tarefa de reconhecimento social, mostrando redução significativa do tempo de investigação social. No labirinto aquático de Morris, não foi visto efeito significativo na memória espacial, ao comparar o tempo desprendido no quadrante correto entre os diferentes tratamentos. Na esquiva inibitória a latência de descida da plataforma, observada na sessão teste, sugere que o tratamento com a dose $150 \mathrm{mg} / \mathrm{kg}$ de $R$. officinallis tem um efeito positivo na memória de longo prazo, quando administrada na fase de consolidação. Concluise que o extrato de $R$. officinalis nas doses de 150 e $300 \mathrm{mg} / \mathrm{kg}$ foi capaz de modular as memórias de curto e longo prazo dos roedores nas tarefas de reconhecimento social e esquiva inibitoria, respectivamente, e esse efeito modulatório melhorou os processos de aprendizado e memória.

Unitermos: Rosmarinus officinalis/farmacognosia. Rosmarinus officinalis/extrato hidroalcoólico. Memória de curto prazo/estudo experimental. Memória de longo prazo/estudo experimental. Memória espacial/estudo experimental.

\footnotetext{
*Correspondence: S. S. Roman. Regional Integrated University of High Uruguay and Missions, URI-Campus Erechim Rio Grande do Sul. Av. Sete de Setembro, 1621 - 99700 - 000 - Erechim - RS, Brasil. E-mail: roman@uricer.edu.br
} 


\section{INTRODUCTION}

Rosmarinus officinalis (Lamiaceae), rosemary, is a perennial herb native to the Mediterranean region but is widely distributed in many parts of the world, including Brazil (Nissen et al., 2000). Among the species of the genus Rosmarinus that grow wild in Brazil, R. officinalis L. is economically important because the leaves are commonly used as a condiment for flavoring food and as a source of antioxidant compounds employed in food preservation (Albuquerque et al., 2007).

$R$. officinalis is widely used in Brazilian folk medicine as a sedative, antispasmodic, cardiotonic, for treating menstrual disturbances, cough, influenza, colic, fever, pain, flatulence, stomach ache, and intestinal, hepatic and renal problems. This herb is also used as a medicine in the treatment of respiratory inflammatory diseases, such as bronchial asthma (Nissen et al., 2000). Some studies have reported a variety of pharmacological activities of $R$. officinalis extract, such as hepatoprotection (Sotelo et al., 2003).

$R$. officinalis extract shows significant pharmacological activity as an antioxidant (Inani et al., 1983), diuretic (Haloui et al., 2000), antinociceptive (González et al., 2007) and antiulcerogenic at doses of 500 and 1000 $\mathrm{mg} / \mathrm{kg}$ (hydroalcoholic), which inhibit 70 and $74.6 \%$, respectively, of lesion ulcerations (Dias et al., 2000).

In animal models predictive of antidepressant properties, $R$. officinalis produces a specific antidepressant-like effect. Moreover, the effect of acute or repeated administration of this extract was similar to the action produced by the classical antidepressant fluoxetine. In addition, it was shown that the antidepressant-like effect of $R$. officinalis is dependent on its interaction with the serotonergic, noradrenergic and dopaminergic systems (Machado et al., 2009).

Some findings indicate that the olfactory properties of rosemary essential oil can produce objective effects on cognitive performance and a significant enhancement of overall memory quality and secondary memory factors (Moss et al., 2003).

Studies using animal models have shown that memory formation involves a series of biochemical changes in several areas of the central nervous system, including the hippocampus. The biochemical events involved in memory formation initially include the activation of $\mathrm{N}$ methyl-D-aspartate (NMDA) and metabotropic (mGluRs) glutamate receptors and the biochemical cascades in neurons (Izquierdo, Medina, 1997).

This study considered the possibility of assessing the effects of phytotherapy on memory and the current literature that indicates that rosemary essential oil affects memory when inhaled by humans. Therefore, the aim of this study was to evaluate whether the oral administration of a hydroalcoholic extract of Rosmarinus officinalis has an effect on the short- and long-term memory of mice in three different tasks used to evaluate learning and memory.

\section{METHODS}

The experiments were performed at the Laboratories of Vegetable Biotechnology and Animal Experimentation of the Regional Integrated University of High Uruguay and Missions - URI - Campus Erechim/RS. The research project was submitted to and approved by the Research Ethics Committee (CEP) of the Regional Integrated University of High Uruguay and Mission, URI-Campus Erechim/RS, under registration No. 184/TCA/09.

\section{Preparation of the extract}

The plant material was ground in a grinder and the hydroalcoholic extract of Rosmarinus officinalis (ROHE) was obtained from $50 \mathrm{~g}$ of powder. The extract remained submerged for 10 days in an alcohol and water solution. Three solution exchanges were performed to avoid alcohol saturation and attempt to maximally extract the compounds present in the plant. The extract was slowly concentrated in a greenhouse at $30{ }^{\circ} \mathrm{C}$ for 5 days. The obtained powder was resuspended in distilled water to prepare the concentrations for the present study.

\section{Experimental animals}

This study used Swiss male mice that were approximately $35 \mathrm{~g}$ (adults, 8 -weeks-old). The mice were acquired from the Laboratory of Animal Testing at the university. The mice were kept in a room under a controlled temperature $\left(23 \pm 1{ }^{\circ} \mathrm{C}\right)$ and were subjected to a $12 \mathrm{~h}$ light cycle (lights on at 7:00 a.m.) with free access to food and water. The experiments were performed during the day (from 13:00 to 18:00). All procedures used in the present study complied with the guidelines of the Brazilian Society of Laboratory Animal Science (SBCAL).

\section{MEMORY MODELS}

\section{Social recognition task}

Short-term social memory was assessed with a slightly modified social recognition task (SR), described by Prediger (Prediger et al., 2008). The adult mice were housed in plastic cages and remained in identical environments until individualized on the day of the task. The 
task was scored by one trained observer (that was blind to the treatments of the animals) in an observation room in which the mice were habituated for 1 hour before the beginning of the task.

The social recognition task consisted of two successive presentations ( 5 min each) separated by a short period of time in which a different mouse was placed in the home cage of another adult mouse. The duration that the resident mouse spent investigating the intruder mouse (sniffing, grooming or pawing) was recorded. At the end of the first presentation, each mouse was removed and remained in its home cage during the delay period and was then re-exposed to the intruder mouse after $120 \mathrm{~min}$.

In this type of task, adult male mice usually display significantly reduced recognition in their social investigation time during the second presentation period (Prediger, Takahashi, 2003). However, when different mouse is re-exposed to the adult mouse in the task and there is no recognition, the social investigation time is similar in both the first and second presentations. In other words, there is no formation of social memory if recognition no occurs (Moura, Xavier, 2010).

\section{Morris water maze task}

Morris water maze (MWM) training and test sessions were performed in a circular swimming pool similar to that described by Morris (Morris et al., 1982). The apparatus was constructed of black-painted iron, had a $1.0 \mathrm{~m}$ inside diameter, was $0.35 \mathrm{~m}$ high, and filled to a depth of $0.3 \mathrm{~m}$ with water maintained at $23^{\circ} \mathrm{C}$. The circular platform $(10 \mathrm{~cm} \times 10 \mathrm{~cm})$ was constructed of black plastic and was submerged $1-1.5 \mathrm{~cm}$ beneath the surface of the water. The outside of the pool, north $(\mathrm{N})$, south $(\mathrm{S})$, east (E) and west (W) were marked for four distant visual cues $(45 \mathrm{~cm} \times 45 \mathrm{~cm})$ that were placed on the walls of the water maze room. The cues were positioned with $30 \mathrm{~cm}$ exposed above the upper edge of the water tank. In the standard setting, the position of each symbol marked the midpoint of the perimeter of a quadrant $($ circle $=$ NE quadrant, square $=\mathrm{SE}$ quadrant, cross $=\mathrm{SW}$ quadrant, and triangle $=\mathrm{NW}$ quadrant). A video-recording system was installed adjacently.

The training session consisted of 4consecutive trials during which the mice were placed in the tank facing the wall and were allowed to swim freely to the submerged platform. If the animal did not find the platform within $60 \mathrm{~s}$, it was gently guided to it. After the platform was detected, the mouse was allowed to remain on the platform for $10 \mathrm{~s}$. The mouse was then removed from the tank for $20 \mathrm{~s}$ before it was placed at the next starting point in the tank. This procedure was performed two times per quad- rant. The test session was performed on the fifth day of training. The test session consisted of a $60 \mathrm{~s}$ probe trial in which the platform was removed from the pool. The seconds spent in the correct quadrant (where the platform had been located in the training sessions) were recorded.

\section{Inhibitory avoidance task}

The inhibitory avoidance (IA) apparatus was an acrylic box $(45 \mathrm{~cm} \times 25 \mathrm{~cm} \times 25 \mathrm{~cm})$ with a floor that consisted of parallel stainless-steel bars (1 $\mathrm{mm}$ diameter) spaced $1 \mathrm{~cm}$ apart. A platform ( $8 \mathrm{~cm}$ wide $\times 2.5 \mathrm{~cm}$ high) was placed on the floor against the left wall. The mice were placed on the platform and their latency to step down on the grid with all four paws was measured. The mice were submitted to the inhibitory avoidance task using a protocol similar to one described previously (Barros et al., 2005). During the training sessions, the animals received a $0.4 \mathrm{~mA} 1.0 \mathrm{~s}$ scrambled foot shock immediately after stepping on the grid (the trials were a maximum of $60 \mathrm{~s}$ ) (Joshi, Megeri, 2008). During the test sessions, no foot shock was administered and the stepdown latency was recorded (the trials were a maximum of 180 s) (Roesler et al., 2003).

The animals were submitted to a single training session. To evaluate long-term memory, the test sessions were performed 24 hours after training. The difference between the latency of the test and training sessions was considered as a measure of memory. Latencies that exceeded the standards were disregarded.

\section{Treatments}

Independent groups of animals were used for each behavioral task. The experimental groups were treated with ROHE (10, 150 and $300 \mathrm{mg} / \mathrm{kg})$, the positive control group received caffeine $(10 \mathrm{mg} / \mathrm{kg})$ and the negative control group received distilled water. All treatments were administered orally. In the Morris water maze task, the animals were treated $30 \mathrm{~min}$ before the test session to assess the retrieval process (which takes place when the animal is exposed to the learning context for the second time). In the inhibitory avoidance task, the groups were treated 4 hours after the training session to assess the consolidation process. In the social recognition task, the animals were treated $30 \mathrm{~min}$ before the initial presentation to assess the acquisition phase of learning.

\section{Statistical analysis}

Data from the social recognition and Morris water maze tasks were analyzed using a Kruskal-Wallis one-way 
analysis of variance by ranks test followed by a NewmanKeuls test when appropriate $(\mathrm{p}<0.05)$. In the inhibitory avoidance task, training and test sessions step-down latencies were compared between groups using a Wilcoxon signed-rank test. The data are shown as the means \pm Standard Deviation (S.D.), and all tests were performed using the Statistica ${ }^{\circledR}$ software package (Statsoft, Tulsa, USA).

\section{RESULTS}

\section{The effects of rosemary on social recognition memory}

The results for the effects of the oral administration of ROHE $(10,150$ and $300 \mathrm{mg} / \mathrm{kg})$ or caffeine $(10 \mathrm{mg} /$ $\mathrm{kg}$ ) on the acquisition of social recognition memory are presented in Figure 1.

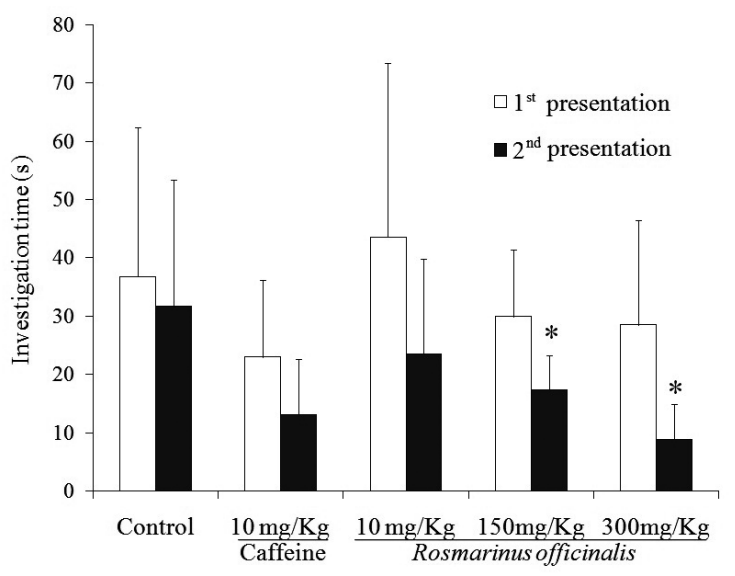

FIGURE 1 - The effects of oral administration of ROHE (10, 150 and $300 \mathrm{mg} / \mathrm{kg})$ or caffeine $(10 \mathrm{mg} / \mathrm{kg})$ on social investigation time of adult mice when the different mouse was re-exposed at $120 \mathrm{~min}$ after the first presentations. The data are shown as \pm S.D. of investigation time ( $n=6$ animals per group). $* p<0.05$ compared to the first presentation of the same group (Newman-Keuls test).

All groups showed a decrease in the time of social investigation (social behavior) during the second presentation. However, the Newman-Keuls test did not reveal any significant effects in the control or caffeine treated groups.

ROHE administered at 150 and $300 \mathrm{mg} / \mathrm{kg}$ produced a significant decrease in the investigation time during the second presentation, which indicates an improvement in the acquisition process. These behavioral modulation effects support their potential efficacy on social short-term memory. No facilitated effect on the acquisition of shortterm memory was observed at $10 \mathrm{mg} / \mathrm{kg}$ ROHE because the decrease of social behavior in the second presentation was not significant.

\section{The effects of rosemary on the Morris water maze task}

The results for the effects of oral administration of $\operatorname{ROHE}(10,150$ and $300 \mathrm{mg} / \mathrm{kg})$ or caffeine $(10 \mathrm{mg} / \mathrm{kg})$ on the retrieval process of spatial long-term memory of mice are presented in Figure 2.

No significant effect was observed for the time spent in the correct quadrant in either the treatment with caffeine or ROHE (Figure 2). Therefore, the group treated with $150 \mathrm{mg} / \mathrm{kg}$ of ROHE spent less time in the opposite quadrant of the submerged platform (data not shown). ROHE does not appear to modulate spatial learning because no significant effect was observed in the time spent in the correct quadrant.

Caffeine administered at $10 \mathrm{mg} / \mathrm{kg}$ did not facilitate the retrieval process. The caffeine treatment enhanced the time spent in the correct quadrant but was not significant. ROHE administered at $300 \mathrm{mg} / \mathrm{kg}$ also enhanced the time spent in the correct quadrant but was not significant (Figure 2).

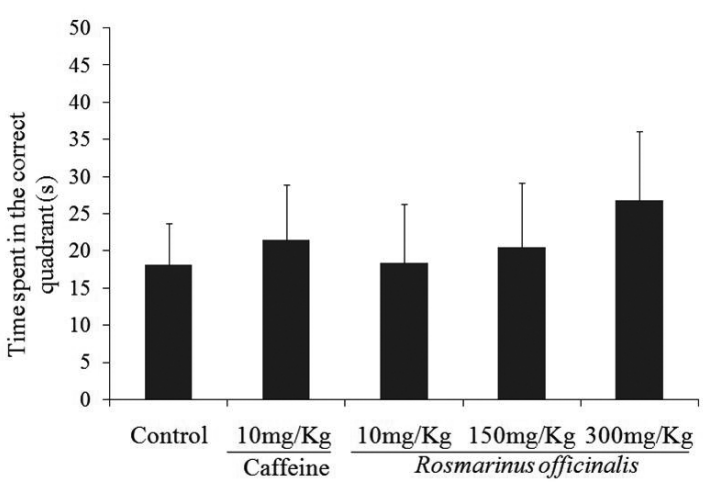

FIGURE 2 - Effects of oral administration of ROHE (10, 150 and $300 \mathrm{mg} / \mathrm{kg}$ ) or caffeine $(10 \mathrm{mg} / \mathrm{kg})$ on spatial long-term-memory of mice evaluated in the Morris water maze task. The data are shown as means $\pm \mathrm{SD}$ of time spent in the correct quadrant $(\mathrm{n}=8-10$ animals per group). No significance was found.

\section{The effects of rosemary on the inhibitory avoidance task}

Figure 3 presents the results for the effects of oral administration of ROHE (10, 150 and $300 \mathrm{mg} / \mathrm{kg})$ and caffeine $(10 \mathrm{mg} / \mathrm{kg})$ on the consolidation process of mice evaluated in the step-down inhibitory avoidance task for long-term memory.

The results indicate that $10 \mathrm{mg} / \mathrm{kg}$ of caffeine can modulate the consolidation process of long-term memory 
because a significant effect was observed in the inhibitory avoidance task. This group had enhanced step-down latencies, which indicate an affected long-term memory in contrast to the observations in the social recognition and Morris water maze tasks.

The results obtained for the $150 \mathrm{mg} / \mathrm{kg}$ ROHE treated group strongly indicate that ROHE can improve the long-term retention of a step-down inhibitory avoidance task in mice. This dosage shows increased step-down latencies compared to the negative controls in the test session. A ROHE dose of $300 \mathrm{mg} / \mathrm{kg}$ also indicates an increased step-down latency in the test session, although no significant effect was observed at this dose.

The $10 \mathrm{mg} / \mathrm{kg}$ ROHE treated group showed an impairment of long-term memory, which indicates that the positive effects observed in the ROHE treated groups might be in relation to high doses.

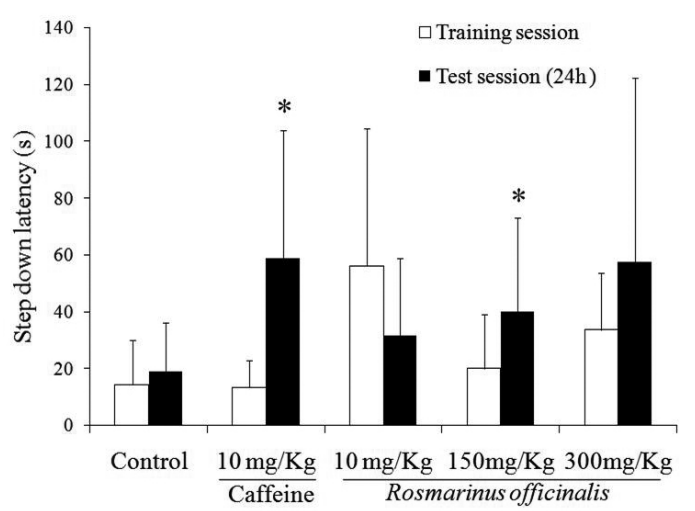

FIGURE 3- The effects of oral administration of ROHE (10, 150 and $300 \mathrm{mg} / \mathrm{kg}$ ) or caffeine $(10 \mathrm{mg} / \mathrm{kg})$ on long-term memory of mice evaluated in the step-down inhibitory avoidance. The data are shown as means \pm SD of step-down latencies $(n=8-10$ animals per group). ${ }^{*} \mathrm{p}<0.05$ when compared training and test session of the same group (Wilcoxon test).

\section{DISCUSSION}

The investigation of the pharmacology of memory between the 1960s and 1980s involved the analysis of the modulation of memory, namely the drugs, hormones, neurotransmitters and neuromodulators that affect memory consolidation. The studies showed that modulatory substances could influence the basic mechanisms of memory processing (Bär et al., 1982).

Memory is often considered to be a process that has several stages, including acquisition, consolidation and retrieval (Abel, Lattal, 2001). A number of pharmaceutical compounds have been used for their cognitive enhancing properties. Memory improving drugs generally work by altering the neurotransmitters in the brain that are involved in the initial learning of a memory or its subsequent reinforcement (Ingole et al., 2008).

Caffeine is one of the most globally consumed substances and produces psychostimulant effects on the central nervous system (CNS) (Fredholm et al., 1999). When administered intraperitoneally, a dose of $10 \mathrm{mg} / \mathrm{kg}$ has been shown to modulate social recognition memory (Prediger et al., 2008). In the present study, the caffeine treated group did not show modulation in either the acquisition or retrieval processes in the social recognition or Morris water maze tasks. One potential hypothesis is that caffeine did not affect the acquisition or retrieval learning phases. Alternatively, caffeine may not have had adequate time to act in the body; the results show that caffeine can modulate consolidation, as shown by the test session results obtained 24 hours after caffeine administration.

The result that caffeine could modulate the consolidation process when long-term memory was accessed in inhibitory avoidance is in agreement with previous research. Treatment with $10 \mathrm{mg} / \mathrm{kg}$ (i.p.) of caffeine for 4 days did not prevent scopolamine-induced impairment in the acquisition phase when long-term memory was assessed. However, in relation to consolidation memory, pre-treatment with caffeine prevented the disruption of short- and long-term memory caused by scopolamine (Botton et al., 2010).

When the acquisition phase of learning was assessed in an SR task, the present results indicate that an acute oral treatment of 150 and $300 \mathrm{mg} / \mathrm{kg}$ ROHE may improve shortterm memory in mice. This memory model is based on the fact that rodents spent more time investigating unfamiliar juvenile conspecifics than familiar ones. When the same juvenile is presented twice, the duration of the investigation decreases in the second meeting (Dantzer et al., 1987). In the present study, an accentuated decrease of investigation was observed in the ROHE treated group, but it must be considered that the conspecific was not a juvenile.

The pre-test administration of drugs may affect the retrieval process, which interferes with the reactivation of memories. A variety of factors can modify memory retrieval during testing (McGaugh, 2000). The ROHE treatment was ineffective when the retrieval phase of learning was assessed and a ROHE treatment did not affect the spatial memory in the Morris water maze task.

Moss et al. (2003) assessed the effects of no scent, lavender and rosemary essential oils on human memory performance. The authors observed that subjects in the rosemary aromatherapy condition exhibited a significant enhancement in memory task performance. Rosemary powder, at a dose closest to normal culinary consumption, 
demonstrated positive effects on the speed of memory, which is a potentially useful predictor of cognitive function in aging (Pengelly et al., 2012)

The IA task involves the formation of a memory in which the animal learns to inhibit a response to not receive an aversive stimulus (Izquierdo, 2002). It has been shown in rats that the levels of hippocampal proteins and the synthesis of glycoproteins, showed 2 peaks after the acquisition of new memories: the initial peak occurred approximately one hour after memorization and the second peak between three to 6 hours after memorization (Matthies, 1982, 1989).

In previous memory studies, when the drugs are administered after training, but not before, the consolidation of memory can be attributed to influences from the drug's effects, which is a process that occurs immediately after the training experience (Castellano et al., 2001; McGaugh, 1989).

The effects of 4 hours of post-training ROHE administration on the consolidation process were evaluated. The results of the present experiments showed that a post-training administration of $150 \mathrm{mg} / \mathrm{kg} \mathrm{ROHE}$ significantly improve the consolidation of long-term memory in the IA when the test sessions were performed 24 hours later; however, the ROHE mechanism is poorly understood.

The acute oral administration of $10 \mathrm{mg} / \mathrm{kg}$ ROHE was ineffective to improve short- and long-term memory and did not affect acquisition, consolidation, or the retrieval learning process. This dose likely had a low quantity of the active compounds that are responsible for positive effects, and a chronic administration could potentially be required. The only effect observed was impairment in the consolidation process in the IA task, although there was no significant effect.

Rosmarinus officinalis extracts contain a number of potentially active components including 1,8-cineole, alpha-pinene, camphor, and borneol (Leung, Foster, 1996). Activity is also exhibited by the essential oil; activity is most likely because of the summation of the activities of several components (Mata et al., 2007; Orhan et al., 2008) because of the variations encountered in the essential oil of identical species of different origins (Sacchetti et al., 2005)

In the 1980s, the discovery of injury and ensuing hypoactivity of the basal nucleus of Meynert's cholinergic hypothesis generated the pathology of Alzheimer's, thereby postulating that acetylcholine was the main neurotransmitter involved in memory. However, similar deficits were observed in the dopaminergic, central noradrenergic and serotonergic systems (Izquierdo, 2002).
Thus, the aim of many treatment regimens is to support the use of muscarinic agonists or inhibitors of acetylcholinesterase (AChE), in which the latter is able to increase the concentration of acetylcholine (Holzgrabe et al., 2007). The facilitation of social memory in mice produced by ROHE could be because of the interaction between ROHE and the cholinergic neurotransmitter systems.

Rosemary has been evaluated using different in vitro and in vivo models to show their efficacy in the management of patients with AD. The studies have demonstrated that extracts from plants of the Lamiaceae family are active in the inhibition of AChE and $\beta$-amyloid deposits. In addition, antioxidant, cytoprotective and anti-inflammatory activities have been observed in Lamiaceae plant extracts (Ożarowski et al., 2009).

AChE inhibitory activity has been detected in aqueous and methanol extracts of RO and was shown to have 12 and $17 \%$ inhibition, respectively, at $0.1 \mathrm{mg} / \mathrm{mL}$ concentration in vitro (Adsersen et al., 2006). There are reports that the compounds 1,8-cineole and alpha-terpineol inhibit AChE, and notably, 1,8-cineole is the most potent inhibitor (Savelev et al., 2003).

These studies indicate that RO may generate activity in the cholinergic system. Machado et al. (2009) also evaluated the antidepressant effect of rosemary extract in mice and concluded that the effect could be attributed to the interaction of rosemary with other neurotransmitter systems, such as the serotonergic, noradrenergic and dopaminergic systems. Neurotransmitter interactions may be responsible for the cognitive enhancements observed in the present study.

The use of herbal medicines in the treatment of memory and diseases such as Alzheimer's could be important because most of the compounds currently studied have toxic effects or may induce dependence (Izquierdo, 2002). $R$. officinalis $L$. has a reputation for improving memory and has been a symbol of remembrance in Europe (Moss et al., 2003).

\section{CONCLUSION}

The results of this study indicated that $R$. officinalis have properties to improve short and long-term memory processes in social recognition and in step-down inhibitory avoidance tasks. The treatment with 150 and $300 \mathrm{mg} / \mathrm{kg}$ of ROHE improved the acquisition phase of learning of a new social short-term memory. The treatment with $150 \mathrm{mg} / \mathrm{kg}$ of $R$. officinalis improved long-term memory when administered in the consolidation phase of learning. Additional research would be required to determine the exact mechanisms of ROHE on memory and learning processes. 


\section{ACKNOWLEDGEMENTS}

The authors thank to Professor Claudio Augusto Zakrzevski and Professor Elisabete Maria Zanin for the kindly contribution in this work.

\section{REFERENCES}

ABEL, T.; LATTAL, K.M. Molecular mechanisms of memory acquisition, consolidation and retrieval. Curr. Opin. Neurobiol., v.11, p.180-187, 2001.

ADSERSEN, A.; GAUGUIN, B.; GUDIKSEN, L.; JAGER, A.K. Screening of plants used in Danish folk medicine to treat memory dysfunction for acetylcholinesterase inhibitory activity. J. Ethnopharmacol., v.104, p.418-422, 2006.

ALBUQUERQUE, U.P.; MEDEIROS, P.M.; ALMEIDA, A.L.S.; MONTEIRO, J.M.; NETO, E.M.F.; MELO, J.G. Medicinal plants of the caatinga (semi-arid) vegetation of NE Brazil: A quantitative approach. J. Ethnopharmacol., v.114, p.325-354, 2007.

ARDENGHI, P.; BARROS, D.M.; IZQUIERDO, L.A.; BEVILAQUA, L.; SCHRODER, N.; QUEVEDO, J. Late and prolonged memory modulation in entorhinal and parietal cortex by drugs acting on the camp/protein kinase. A signaling pathway. Behav. Pharmacol., v.8, p.745-751, 1997.

BÄR, P.R.; JOLLES, J.; OESTREICHER, A.B.; ZWIERS, H.; SOMEREN, H.; SCHOTMAN, P.; GISPEN, W.H. Phosphorylation of synaptic membrane constituents: target of modulation by behaviourally active neuroptides. In: AJMONE-MARSAN, C.; MATTHIES, H. (Eds.). Neuronal plasticity and memory formation. New York: Raven Press, p.123-136, 1982.

BARROS, D.M.; RAMIREZ, M.R.; IZQUIERDO, I. Modulation of working, short- and long-term memory by nicotinic receptors in the basolateral amygdala in rats. Neurobiol. Learn. Mem., v.83, p.113-118, 2005.

BEVILAQUA, L.; ARDENGHI, P.; SCHRODER, N.; BROMBERG, E.; SCHMITZ, P.K.; SCHAEFFER, E. Drugs that influence the cyclic adenosine monophosphate/protein kinase. A signaling patway alter memory consolidation when given late after training into rat hippocampus but not amygdala. Behav. Pharmacol., v.8, p.331-338, 1997.
BOTTON, P.H.; COSTA, M.S.; ARDAIS, A.P.; MIORANZZA, S.; SOUZA, D.O.; ROCHA, J.B.T.; PORCIÚNCULA, L.O. Caffeine prevents disruption of memory consolidation in the inhibitory avoidance and novel object recognition tasks by scopolamine in adult mice. Behav. Brain Research, v.214, p.254-259, 2010.

CASTELlanO, C.; CESTARI, V.; CIAMEI, A. NMDA receptors and learning and memory processes. Curr. Drug Targets, v.2, p.273-283, 2001

DIAS, P.C.; FOGLIO, M.A.; POSSENTI, A.; CARVALHO, J.E. Antiulcerogenic activity of crude hydroalcoholic extract of Rosmarinus officinalis L. J. Ethnopharmacol., v.69, p.57-62, 2000.

DANTZER, R.; BLUTHE, R.M.; KOOB, G.F.; Le MOAL, M. Modulation of social memory in male rats by neurohypophyseal peptides. Psychopharmacol., v.91, p.363-368, 1987.

FREDHOLM, B.B.; BÄTTIG, K.; HOLMÉN, J.; NEHLIG, A.; ZVARTAU, E.E. Actions of caffeine in the brain with special reference to factors that contribute to its widespread use. Pharmacol. Rev., v.51, p.83-133, 1999.

GONZÁLEZ, T.M.E.; PEÑA, E.I.; MARTÍNEZ, A.L.; MORENO, J.P.; FEFER, P.G.; CAMPOS, M.D.; MUÑOZ, F.J.L. Evaluation of the antinociceptive effect of Rosmarinus officinalis L. using three different experimental models in rodents. J. Ethnopharmacol., v.111, p.476-482, 2007.

HALOUI, M.; LOUEDEC, L.; MICHEL, J.B.; LYOUSSI, B. Experimental diuretic effects of Rosmarinus officinalis and Centaurium erythraea. J. Ethnopharmacol., v.71, p.465472, 2000.

HOLZGRABE, U.; KAPKOVA, P; ALPTUZUN, V.; SCHEIBER, J. KUGELMANN, E. Targetting acetylcholinesterase to treat neurodegeneration. Expert Opin. Ther. Targets, v.11, p.161-179, 2007.

INATANI, R.; NAKATANI, N.; FUWA, H. Antioxidative effect of the constituents of Rosemary (Rosmarinus officinalis L.) and their Derivatives. Agric. Biol. Chem., v.47, p.521-528, 1983.

INGOLE, S.R.; RAJPUT, S.K.; SHARMA, S.S. Cognition Enhancers: Current Strategies and Future Perspectives CRIPS, v.9, p.42-48, 2008. 
IZQUIERDO, I. Memória. São Paulo: Artmed, p.73-86, 2002.

IZQUIERDO, I.; MEDINA, J.H. Memory formation: the sequence of biochemical events in the hippocampus and its connection to activity in other brain structures. Neurobiol. Learn Mem., v.68, p.285-316, 1997.

JOSHI, H.; MEGERI, K. Antiamnesic evaluation of C. phlomidis Linn. bark extract in mice. Braz. J. Pharm. Sci., v.44, p.129-135, 2008.

LEUNG, A.Y.; FOSTER, S. Encyclopedia of common natural ingredients used in food, drugs and cosmetics. New York: John Wiley, 1996. v.40, p.289.

MACHADO, D.G.; BETTIO, L.E.B.; CUNHA, M.P.; CAPRA, J.C.; DALMARCO, J.B.; PIZZOLATTI, M.G.; RODRIGUES, A.L.S. Progress in neuro-antidepressantlike effect of the extract of Rosmarinus officinalis in mice: involvement of the monoaminergic system. Psychopharmacol. Biol. Psych., v.33, p.642-650, 2009.

MATA, A.T.; PROENÇA, C.; FERREIRA, A.R.; SERRALHEIRO, M.L.M.; NOGUEIRA, J.M.F.; ARAUJO, M.E.M. Antioxidant and antiacetylcholinesterase activities of five plants used as Portuguese food spices. Food Chem., v.103, p.778-786, 2007.

McGAUGH, J.L. Dissociating learning and performance: Drug and hormone enhancement of memory storage. Brain Res. Bull., v.23, p.339-345, 1989.

McGAUGH, J. L. Memory-a century of consolidation. Science, v.287, p.248-251, 2000.

MATTHIES, H. In search of the cellular mechanisms of memory. Prog. Neurobiol., v.32, p.277-349, 1989.

MATTHIES, H. Plasticity in the nervous system: an approach to memory research. In: AJMONE-MARSAN, C.; MATTHIES, H., (Eds.). Neuronal plasticity and memory formation. New York: Raven Press, 1982. p.1-15.

MORRIS, R.G.; GARRUD, P.; RAWLINS, J.N.; O'KEEFE, J. Place navigation impaired in rats with hippocampal lesions. Nature, v.297, p.681-683, 1982.

MOSS, M.; COOK, J.; WESNES, K. Aromas of rosemary and lavender essential oils differentially affects cognition and mood in healthy adults. Int. J. Neurosci., v.38, p.113-115, 2003.
MOURA, P.J.; XAVIER, G.F. Memória de reconhecimento social em ratos. Pscicol., v.21, p.355-389, 2010.

NISSEN, L.R.; MANSSON, L.; BERTELSEN, G.; HUYNHBA, T.; SKIBSTED, L.H. Protection of dehydrated chicken meat by natural antioxidants as evaluated by electron spin resonance spectrometry. J. Agric. Food Chem., v.48, p.5548-5556, 2000.

ORHAN, I.; ASLAN, S.; KARTAL, M.; SENER, B.; HÜSNÜ, K. BASER, C. Inhibitory effect of Turkish Rosmarinus officinalis $\mathrm{L}$. on acetylcholinesterase and butyrylcholinesterase enzymes. Food Chem., v.108, p.663668, 2008.

OŻAROWSKI, M.; MIKOŁAJCZAK, P.Ł.; BOBKIEWLCZKOZŁOWSKA, T.; KUJAWSKI, R.; MROZIKIEWICZ, P.M. Neuroactive compounds from medicinal plants of the Lamiaceae family showing potentially beneficial activity in treatment of Alzheimer's disease. Herba Polonica, v.55, p.148-163, 2009.

PENGELLY, A.; SNOW, J.; MILLS, S.Y.; SCHOLEY, A.; WESNES, K.; BUTLER, L.R. Short-term study on the effects of rosemary on cognitive function in an elderly population. J. Med. Food., v.15, p.10-17, 2012.

PREDIGER, D.S.R.; FERNANDES, S.M.; RIAL, D.; WOPEREIS, S.; PEREIRA, S.P.; BOSSE, S.T.; SILVA, B.C.; CARRADORE, S.R.; MACHADO, S.M.; FILHO, C.V.; CAMPOS, L.C. Effects of acute administration of the hydroalcoholic extract of mate tea leaves (Ilex paraguariensis) in animal models of learning and memory. J. Ethnopharmacol., v.120, p.465-473, 2008.

PREDIGER, R.D.; TAKAHASHI, R.N. Ethanol improves short-term social memory in rats. Involvement of opioid and muscarinic receptors. Eur. J. Pharmacol., v.462, p.115$123,2003$.

ROESLER, R.; SCHRÖDER, N.; VIANNA, M.R. Differential involvement of hippocampal and amygdalar NMDA receptors in contextual and aversive aspects of inhibitory avoidance memory in rats. Brain Res., v.975, p.207-213, 2003.

SACCHETTI, G..; MAIETTI, S.; MUOLI, M.V.; SCAGLIANTI, M.; MANFREDINI, S.; RADICE, M.; BRUNI, R. Comparative evaluation of 11 essential oils of different origin as functional antioxidants, antiradicals, and antimicrobials in food. Food Chem., v.91, p.621-632, 2005. 
SOTELO, F.J.I.; MARTINEZ, F.D.; MURIEL, P.; SANTILLÁN, R.L.; CASTILLO, D.; YAHUACA, P. Evaluation of the effectiveness of Rosmarinus officinalis (Lamiaceae) in the alleviation of carbon tetrachloride-induced acute hepatotoxicity in the rat. J. Ethnopharmacol., v.81, p.145$154,2002$.
SAVELEV, S.; OKELLO, E.; PERRY, N.S.L.; WILKINS, R.M.; PERRY, E.K. Synergistic and antagonistic interactions of anticholinesterase terpenoids in Salvia lavandulaefolia essential oil. Pharmacol. Biochem. Behav., v.75, p.661$668,2003$.

Received for publication on $25^{\text {th }}$ January 2012. Accepted for publication on $11^{\text {th }}$ July 2012. 
